\title{
Peningkatan Kapasitas Guru Sekolah Piloting dalam Lesson Study for Learning Community di SMP Muhammadiyah 1 Malang
}

\author{
${ }^{1}$ Fuad Jaya Miharja, ${ }^{1}$ H. Husamah, ${ }^{2}$ M. Masrudi \\ ${ }^{1}$ Prodi Pendidikan Biologi, FKIP, Universitas Muhammadiyah Malang, Jl. Raya Tlogomas \\ No. 246, Malang, Indonesia 65144 \\ ${ }^{2}$ SMP Muhammadiyah 1 Kota Malang, Jl. Slamet Riadi No. 134, Malang, Indonesia
}

Email Korespondensi: fuad.jayamiharja@umm.ac.id

\begin{tabular}{|c|c|}
\hline Article Info & bstract \\
\hline $\begin{array}{l}\text { Article History } \\
\text { Received: } 2020-10-23 \\
\text { Revised: } 2020-10-26 \\
\text { Published: } 2020-10-30\end{array}$ & \multirow{2}{*}{$\begin{array}{l}\text { Capacity building for piloting school teachers in lesson study for learning } \\
\text { community at SMP Muhammadiyah } 1 \text { Malang. The LSLC mentoring } \\
\text { program at Muhammadiyah Schools has entered its third year, and the } \\
\text { program continues to be refined. In its implementation, the availability of } \\
\text { learning documentation is still a challenge that needs to be resolved because } \\
\text { empirical documentation is a fundamental aspect of reflection and follow-up } \\
\text { planning. Mentoring was carried out during March-May } 2020 \text { at SMP } \\
\text { Muhammadiyah } 1 \text { Malang. The implementation method that refers to the } \\
\text { situation analysis of the programs that have been agreed upon with the school } \\
\text { is shared perceptions discussions, workshops, mentoring, and monitoring and } \\
\text { evaluation. Mentoring activities have initiated the teacher to interpret LSLC as } \\
\text { a learning community and understand the basic techniques of carrying out } \\
\text { observations comprehensively. }\end{array}$} \\
\hline $\begin{array}{l}\text { Keywo } \\
\text { Collab } \\
\text { Learni } \\
\text { LSLC }\end{array}$ & \\
\hline Infor & Abstrak \\
\hline $\begin{array}{l}\text { Sejarah Artikel } \\
\text { Diterima: } 23-10-2020 \\
\text { Direvisi: } 26-10-2020 \\
\text { Dipublikasi: } 30-10-2020\end{array}$ & \multirow{2}{*}{$\begin{array}{l}\text { Program pendampingan Lesson Study for Learning Community (LSLC) di } \\
\text { Sekolah Muhammadiyah telah memasuki tahun ketiga dan terus dilakukan } \\
\text { penyempurnaan program. Dalam pelaksanaannya ketersediaan dokumentasi } \\
\text { pembelajaran masih menjadi tantangan yang perlu diselesaikan, karena } \\
\text { ketersediaan dokumentasi empiric merupakan aspek fundamental dalam } \\
\text { melakukan refleksi dan rencana tindaklanjut. Pendampingan dilaksanakan } \\
\text { selama bulan Maret - Juli } 2020 \text { di SMP Muhammadiyah } 1 \text { Malang. Metode } \\
\text { pelaksanaan yang mengacu kepada analisis situasi program-program yang } \\
\text { disepakati bersama dengan pihak sekolah adalah diskusi penyamaan persepsi, } \\
\text { lokakarya, pendampingan, dan monitoring evaluasi. Kegiatan pendampingan } \\
\text { telah menginisiasi guru dalam memaknai LSLC sebagai komunitas belajar dan } \\
\text { memahami teknik dasar pelaksanaan observasi secara komprehensif }\end{array}$} \\
\hline $\begin{array}{l}\text { Kata } \\
\text { Kolabc } \\
\text { Komur } \\
\text { LSLC }\end{array}$ & \\
\hline \multicolumn{2}{|c|}{$\begin{array}{l}\text { Sitasi: Miharja, J.F., H. Husamah \& M. Masrudi (2020) Peningkatan Kapasitas Guru Sekolah Piloting } \\
\text { dalam Lesson Study for Learning Community di SMP Muhammadiyah } 1 \text { Malang. Sasambo: Jurnal Abdimas } \\
\text { (Journal of Community Service). 2(3), 134-142. DOI : 10.36312/sasambo.v2i3.311 }\end{array}$} \\
\hline
\end{tabular}

\section{PENDAHULUAN}

Program kerjasama Lesson Study (LS) melalui piloting school lesson study yang dilaksanakan oleh Program Studi Pendidikan Biologi FKIP Universitas Muhammadiyah Malang telah memasuki tahun ketiga dan terus mengalami perkembangan dan perbaikan hingga saat ini (Hindun et al., 2018; Nurwidodo, Hendayana, et al., 2018; Susetyarini \& Miharja, 2017). Perkembangan dan perbaikan yang dilakukan meliputi berbagai komponen yang terlibat dalam proses pembelajaran seperti peran siswa, guru, dan tenaga administrasi sekolah (Asanuma, 2012; Lewis, 2009). Perbaikan yang dilakukan didasarkan pada 
permasalahan dan hambatan yang dihadapi pada pelaksanaan sebelumnya (Persico et al., 2010). Dalam konteks payung pengabdian di Program Studi Pendidikan Biologi FKIP Universitas Muhammadiyah Malang, tema ini memperkaya tema-tema sebelumnya, yaitu lingkungan/Pendidikan lingkungan (Budiyanto et al., 2020; Hasanah et al., 2018; Prihanta et al., 2020), pembelajaran/penguatan guru (Hudha \& Husamah, 2019; Husamah et al., 2018; Permana \& Pantiwati, 2020; Zaenab et al., 2020), pertanian organik (Budiyanto et al., 2020; Budiyanto \& Hadi, 2020), serta nelayan, petanin, dan teknologi tepat guna (Hindun, Mulyono, et al., 2019; Nurwidodo, Rahardjanto, et al., 2018; Rahardjanto et al., 2019). Identifikasi masalah dan hambatan tersebut dirangkum dalam kegiatan monitoring dan evaluasi yang rutin dilakukan.

Dalam pelaksanaannya, implementasi LS sebagai upaya peningkatan kualitas dan mutu pembelajaran dan kompetensi guru membutuhkan banyak dokumentasi empiris yang berkaitan dengan proses pembelajaran siswa serta hal teknis lainnya (Arani et al., 2017; Chong \& Kong, 2012). Ketersediaan dokumen yang dimaksud tidak hanya dokumen tertulis tetapi juga berbagai dokumentasi dalam bentuk catatan, foto, maupun video pembelajaran (Gay et al., 2012). Dokumen-dokumen empiris tersebut yang digunakan sebagai dasar pembahasan pada tahap refleksi.

Menurut beberapa ahli, ketersediaan dokumen dalam bentuk foto dan video pembelajaran memungkinkan guru untuk mengkaji proses belajar yang dilakukan oleh siswa serta kejadian-kejadian unik yang muncul dari aktivitas belajar siswa (Chenault, 2017; Saito et al., 2015). Namun demikian, dokumentasi pembelajaran yang dihasilkan selama ini belum mampu memberikan gambaran yang utuh terkait dengan proses pembelajaran yang dilaksanakan, seperti tidak merekam kegiatan belajar dari awal hingga akhir dan tidak menggambarkan bagaimana proses belajar atau diskusi yang dilakukan siswa. Hal tersebut menghambat analisis kegiatan belajar yang dilakukan pada saat refleksi. Padahal, menurut Nurwidodo et al (2018) dan Sudirtha (2017) kemampuan guru dalam menganalisis pembelajaran merupakan salah satu kompetensi guru professional.

Di lain pihak, sekolah yang terlibat dalam piloting LS memiliki visi dalam mengembangkan lesson study sebagai sebuah gerakan bersama (lesson study for learning community/LSLC). Hasil observasi menunjukkan bahwa kegiatan pembelajaran di sekolah dilaksanakan secara mandiri oleh guru. Dalam perspektif lain, guru cendcrung melakukan desain dan pelaksanaan pembelajaran dengan komunikasi yang minimal dalam komunitas. Diskusi terjadi biasanya di dalam kelompok mata pelajaran serumpun.

Namun demikian, sekolah telah merumuskan kebijakan pelaksanaan LSLC dengan melibatkan berbagai stakeholder. Kegiatan pengabdian yang dilakukan bertujuan untuk memfasilitasi sekolah dalam peningkatan kapasitas guru dalam melakukan observasi pembelajaran dan manajemen LS. Beberapa poin yang dilaksanakan dalam pengabdian ini meliputi 1) pendalaman konsep dan hakikat LSLC, 2) sistem informasi lesson study, dan 3) teknik dasar observasi pembelajaran. Kegiatan pengabdian ini bertujuan untuk merekonstruksi filosofi pembelajaran dalam perspektif learning community dan menginisiasi manajemen berbasis lesson study di sekolah. Kegiatan pengabdian dan luarannya berupa artikel ini akan menjadi best practises bagi masyarakat umum, khususnya peneliti dan praktisi dalam upaya pengembangan dan peningkatan dampak positif LS bagi sekolahsekolah di berbagai wilayah di Indonesia. 


\section{METODE}

Program pengabdian kelompok dilaksanakan di SMP Muhammadiyah 1 Malang pada Bulan Maret - Juli 2020. Pelaksanaan pendampingan menggunakan metode yang mengacu pada analisis situasi program-program yang telah disepakati bersama. Sasaran pengabdian ini meliputi Kepala Sekolah, guru dan tenaga kependidikan. Pelaksanaan pengabdian melalui pendampingan berstruktrur. Metode pendampingan yang dilaksanakan sebagaimana diuraikan pada Gambar 1.

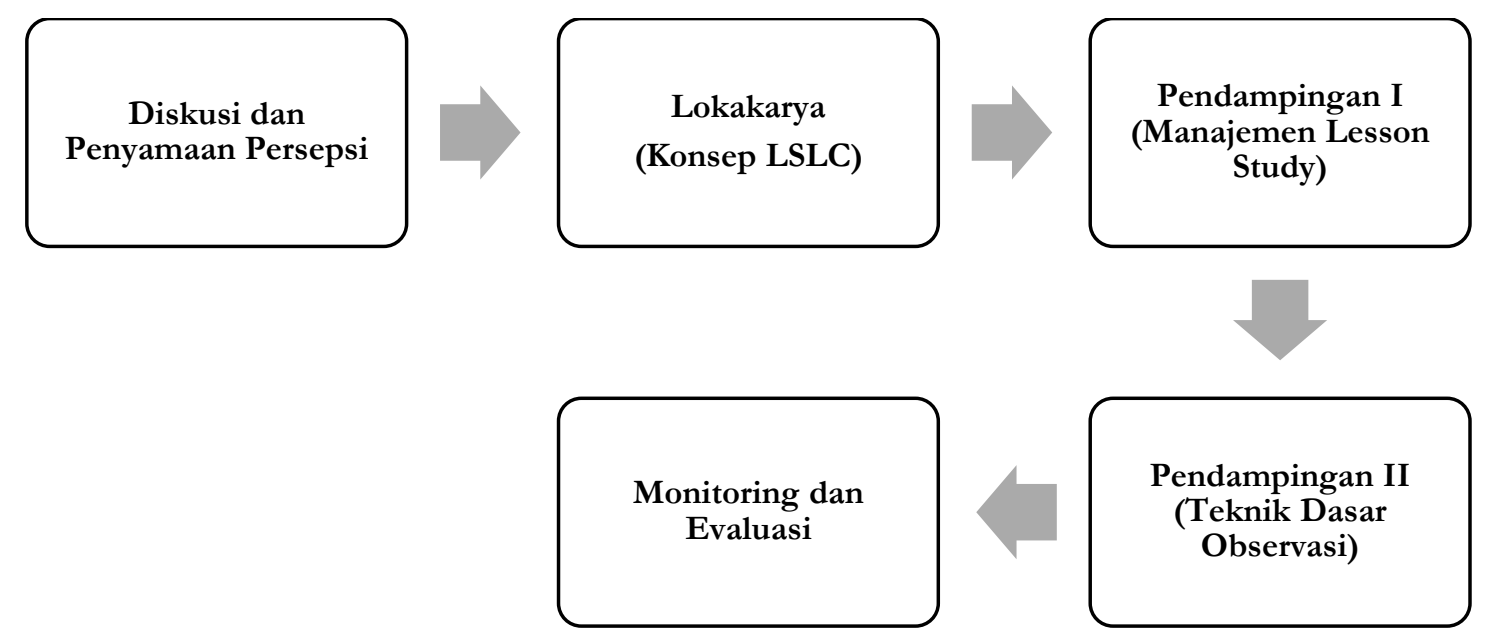

Gambar 1. Proses pendampingan LSLC di SMP Muhammadiyah 1 Malang.

\section{HASIL DAN PEMBAHASAN}

Peningkatan kualitas pembelajaran dan profesionalisme guru merupakan salah satu langkah penting dalam menciptakan pembelajaran yang bermutu. Namun pada kenyataannya, upaya tersebut tidak bisa dilakukan secara parsial dan tidak tersistem (Lim et al., 2018; Prihantoro, 2011; Saito \& Atencio, 2015; Zubaidah, 2010). Peningkatan kualitas pembelajaran hanya bisa dilakukan secara kolaboratif melalui reformasi sekolah (Saito \& Atencio, 2015). Dalam hal ini, LSLC merupakan pengejawantahan dari upaya kolaboratif yang dilakukan secara tersistem di sekolah (Hindun, Nurwidodo, et al., 2019; Saito et al., 2015). Pendalaman konsep learning community dilakukan pada tahap awal kegiatan pendampingan dilakukan. Hal ini bertujuan untuk menyamakan persepsi dan menguatkan konsep serta budaya yang telah dibangun di sekolah. Learning community dibangun atas tiga pondasi filosofi meliputi filosofi publik, demokratis, dan keunggulan.

Filosofi publik berdasarkan pada prinsip keterbukaan pengelolaan pembelajaran. Pada dasarnya, sekolah merupakan bagian dari sistem tata nilai masyarakat yang bertujuan menghasilkan manusia yang mampu memanusiakan manusia (Bakar et al., 2014; Jeong \& Hmelo-Silver, 2016; Jumriani \& K. Prasetyo, 2017). Dalam perspektif lain, sekolah -dengan sistem tata nilai yang dimiliki- melakukan layanan pendidikan kepada siswa berasal dari lingkungan masyarakat sekitar dengan harapan siswa tersebut memiliki seperangkat nilai yang dibutuhkan dalam kehidupan sosial masyarakat (Tsuneyoshi, 2016; Wearmouth, 2017). Filosofi publik dalam learning community dijadikan sebuah landasan bagi sekolah untuk berani membuka pembelajaran kepada stakeholder terkait (Arimoto \& Clark, 2018). Beberapa ahli menyatakan bahwa sekolah membuka ruang kelas untuk memperoleh masukan 
dan/atau penguatan yang signifikan terhadap pelaksanaan pembelajaran (Arani et al., 2017; Saito et al., 2018; Wood, 2018). Dalam pelaksanaannya, dalam perspektif learning community, sekolah mengijinkan guru untuk membuka kelas dan mengundang stakeholder seperti rekan sejawat, praktisi, peneliti, serta orang tua untuk dapat mengobservasi proses pembelajaran yang dilaksanakan.

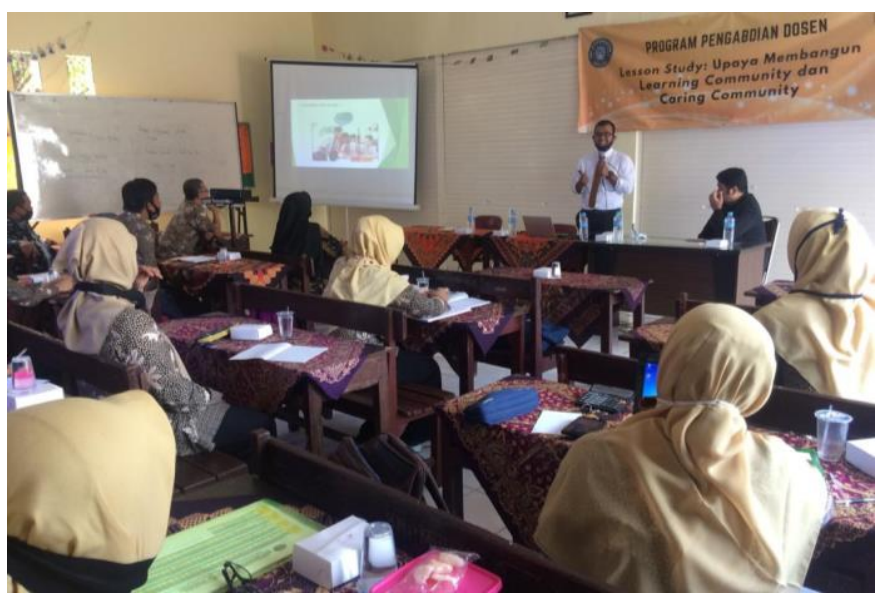

Gambar 2. Lokakarya implementasi LSLC di Sekolah

Filosofi demokratis berlandaskan pada prinsip komunikasi dan keterbukaan antar stakeholder pembelajaran (Gay et al., 2012; Smith \& MacGregor, 1992). Dalam konteks ruang kelas, demokratis tercermin dari aktivitas yang membudayakan cara hidup bersama seperti hubungan saling mendengarkan (Arthur \& Harrison, 2012; Hossain \& Ali, 2014). Guru, sebagai fasilitator, harus dapat membangun ruang kelas yang kondusif dan mengaktifkan dialog yang baik dengan siswa (Alshwaikh \& Adler, 2017; Kaendler et al., 2015). Lebih dari itu, keterbukaan komunikasi antar siswa dan antar guru juga dipandang sebagai factor fundamental dalam implementasi LSLC (Miharja et al., 2020; Saito, 2019). Beberapa peneliti meyakini bahwa demokrasi yang dibangun melalui interaksi di dalam kelas, secara konsisten dapat membangun keterampilan-keterampilan esensial untuk hidup di Abad 21 (Miharja et al., 2020; Saito \& Atencio, 2015; Ueno, 2007).

Implementasi kedua filosofi tersebut, secara komprehensif mendasari filosofi keunggulan dalam LSLC. Sebagaimana Teori Dewey yang menyatakan bahwa pendidikan merupakan suatu upaya pembentukan pembiasaan, filosofi keunggulan LSLC mereformasi visi untuk melakukan upaya terbaik berdasarkan dengan kondisi dan potensi yang ada di sekolah (Pluta et al., 2013; Ueno, 2007; Widiadi \& Utami, 2016). Dalam perspektif lain, sekolah -sebagai sebuah organisasi belajar- mengerahkan semua potensi sumber daya manusia yang dimiliki secara kolaboratif untuk menstimulasi terbentuknya kondisi lingkungan belajar yang menjamin hal belajar setiap siswa (Le et al., 2018; Scager et al., 2016).

Penguatan filosofi pembelajaran melalui LSLC ini direspon positif oleh guru dan tenaga kependidikan. Guru merefleksikan pengalaman dalam pelaksanaan pembelajaran, LS pada khususnya, yang dilakukan di sekolah. Respon guru seperti dijabarkan pada Tabel 1. 
Tabel 1. Respon guru dalam implementasi LSLC di Sekolah

\begin{tabular}{ll}
\hline \multicolumn{1}{c}{ Responden } & \multicolumn{1}{c}{ Respon } \\
\hline Responden 1 & Filosofi LSLC mengubah paradigma dan perspektif saya \\
& dalam mengimplementasikan lesson study. Kesulitan dan \\
& hambatan yang saya alami selama ini karena bergerak \\
& sendiri dalam implementasi lesson study, bukan di dalam \\
& sistem yang dibangun secara kolaboratif \\
\hline Responden 2 & Saya melihat, sekolah memiliki potensi dalam \\
& mengimplementasi lesson study sebagai sebuah gerakan \\
& berbasis pada komunitas belajar. Hubungan yang dekat \\
& dengan masyarakat merupakan salah satu modal penting \\
& dalam implementasi LSLC \\
\hline Responden 3 & LSLC menguatkan kami sebagai sebuah kesatuan yang \\
& bergerak bersama dalam menciptakan lingkungan belajar \\
& yang kondusif bagi siwa. Kolaborasi antar komponen \\
& memudahkan kami dalam melihat sejauh mana \\
& komunikasi di dalam ruang kelas dapat menginisiasi dan \\
& menguatkan tumbuhnya keterampilan Abad 21. \\
\hline
\end{tabular}

Dalam menjamin terciptanya lingkungan belajar yang kondusif, sekolah perlu melakukan observasi pelaksanaan LSLC secara berkelanjutan. Observasi di ruang-ruang kelas merupakan sebuah pendekatan yang dapat memberi gambaran empiris sejauh mana demokrasi belajar terbangun di dalam komunitas belajar (Santoro et al., 2004; Weinberger \& Shonfeld, 2018). Lebih dari itu, kegiatan observasi perlu dikuatkan dengan berbagai media dokumentasi pendukung seperti catatan tertulis, foto aktivitas belajar siswa, serta rekaman video (McKechan \& Ellis, 2014). Dokumentasi tersebut merupakan sumber kekayaan intelektual yang dapat mengungkap berbagai informasi esensial dalam LSLC.

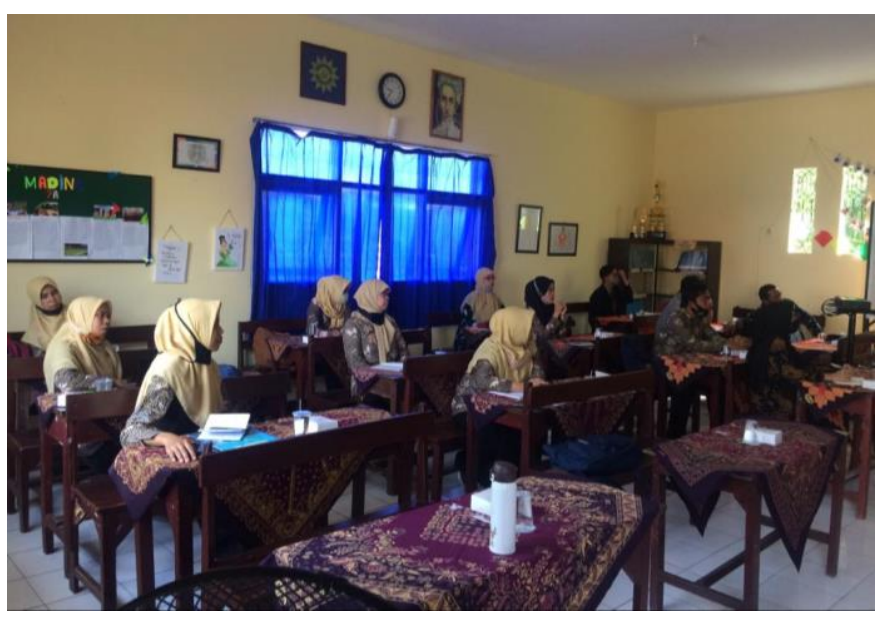

Gambar 3. Penguatan kompetensi secara berkelanjutan sebagai upaya optimalisasi sumber daya manusia

Pada pelaksanaannya, observer perlu memahami dan menginternalisasi teknik dasar observasi untuk memastikan teramatinya informasi-informasi yang esensial (Weinberger \& 
Shonfeld, 2018). Observer perlu memulai dengan mengamati bagaimana seorang siswa belajar. Secara spesifik, fokus observer untuk memperoleh gambaran informasi yang lebih komprehensif tentang bagaimana siswa berpikir dan berinteraksi dengan lingkungannya (Kaendler et al., 2015). Hal tersebut dilakukan observer tidak dapat mengamati pikiran atau perasaan siswa, melainkan pada kegiatan yang merepresentasikan keduanya (Miharja et al., 2020; Summers et al., 2005).

\section{KESIMPULAN}

Pendampingan pelaksanaan LSLC di SMP Muhammadiyah 1 Malang telah diinisiasi dengan penyamaan persepsi seluruh stakeholder yang terlibat dalam pembelajaran. Hal ini merupakan langkah strategis dalam melakukan reformasi visi sekolah. Langkah pendampingan berikutnya tetap dilakukan secara bertahap dan konsisten.

\section{SARAN}

Implementasi LSLC di sekolah merupakan sebuah langkah besar yang perlu dipahami dan ditindaklanjuti secara bersama-sama oleh semua komponen. Keterbukaan dan konsistensi pelaksanaan adalah factor kunci yang terus-menerus dilakukan secara berkelanjutan dalam rangka meminimalisir permasalahan yang ada.

\section{UCAPAN TERIMA KASIH}

Kegiatan pengabdian ini dapat terselenggara atas kerjasama berbagai pihak. Ucapan terimakasih dan penghargaan setinggi-tingginya kepada Direktorat Penelitian dan Pengabdian kepada Masyarakat Universitas Muhammadiyah Malang atas pendanaan yang diberikan melalui skema Program Pengabdian Kelompok Tahun 2020 berdasarkan Surat Tugas No. E.2.a/239/BAA-UMM/III/2020. Terima kasih pula kami sampaikan kepadaKepala dan para guru SMP Muhammadiyah 1 Malang atas kerjasama yang sangat baik dalam kegiatan pengadian ini.

\section{DAFTAR PUSTAKA}

Alshwaikh, J., \& Adler, J. (2017). Researchers and teachers as learners in Lesson Study. In SAARMSTE Book of Long Papers (Issue March). Central University of Technology Free State, South Africa.

Arani, M. R. S., Shibata, Y., Sakamoto, M., Iksan, Z., Amirullah, A. H., \& Lander, B. (2017). How teachers respond to students' mistakes in lessons: A cross-cultural analysis of a mathematics lesson. International Journal for Lesson and Learning Studies, 6(3), 249267. https://doi.org/10.1108/IJLLS-12-2016-0058

Arimoto, M., \& Clark, I. (2018). Equitable assessment interactions in the 'Open Learning Environment' (OLE). European Journal of Education, 53(2), 141-143. https://doi.org/10.1111/ejed.12277

Arthur, J., \& Harrison, T. (2012). Exploring good character and citizenship in England. Asia Pacific Journal of Education, 32(4), 489-497. https://doi.org/10.1080/02188791.2012.741097

Asanuma, S. (2012). Lesson study and curriculum politics in contemporary Japan. Asia Pacific Journal of Educational Development, 1(1), 25-32. https://doi.org/10.6228/APJED.01.01.03

Bakar, Z. A., Yun, L. M., Keow, N. S., \& Li, T. H. (2014). Goal-setting learning principles : a lesson from practitioner. Journal of Education and Learning, 8(1), 41-50. https://doi.org/10.11591/edulearn.v8i1.204 
Budiyanto, M. A. K., \& Hadi, S. (2020). Science and technology for the community of traditional beef cattle farmers who face animal feed problem. Journal of Community Service and Empowerment, 1(1), 37-45. https://doi.org/10.22219/jcse.v1i1.11511

Budiyanto, M. A. K., Waluyo, L., \& Rahadjanto, A. (2020). Pendampingan pembuatan akarisida organik di kelompok tani Sumber Urip-1 Desa Wonorejo Kecamatan Poncokusumo Kabupaten Malang. International Journal of Community Service Learning, 4(1), 10. https://doi.org/10.23887/ijcsl.v4i1.19660

Chenault, K. H. (2017). Building collaborative pedagogy: Lesson Study in higher education. College Quarterly, 20(1).

Chong, W. H., \& Kong, C. A. (2012). Teacher collaborative learning and teacher selfefficacy: The case of lesson study. Journal of Experimental Education, 80(3), 263-283. https://doi.org/10.1080/00220973.2011.596854

Gay, L. R., Mills, G. L., \& Airasian, P. (2012). Educational research: competencies for analysis and application. Pearson.

Hasanah, I., Husamah, H., Harventy, G., \& Satiti, N. R. (2018). Implementasi Sekolah Sedekah Sampah Untuk Mewujudkan Pengelolaan Sampah Berbasis Filantropi di SMP Muhammadiyah Kota Batu. International Journal of Community Service Learning, 2(4), 283-290. https://doi.org/10.23887/ijcsl.v2i4.14364

Hindun, I., Mulyono, M., \& Husamah, H. (2019). Pemanfaatan teknologi tepat guna berbasis solar cell untuk mengatasi permasalahan IRT nelayan Sapeken Kabupaten Sumenep. International Journal of Community Service Learning, 3(4), 198. https://doi.org/10.23887/ijcsl.v3i4.21791

Hindun, I., Nurwidodo, N., Wahyono, P., Miharja, F. J., \& Rais, A. (2019). Implementation of lesson study for learning community (LSLC): Impact on piloting school teachers in Batu City. 9th International Conference on Lesson Study, 204-211.

Hindun, I., Nurwidodo, Wahyono, P., Miharja, F. J., \& Rais, A. (2018). Implementation of lesson study for learning community (LSLC) impact on piloting school teachers in Batu City. International Conference on Lesson Study, 204-211. https://onesearch.id/Record/IOS4109.44395

Hossain, F. M. A., \& Ali, M. K. (2014). Relation between individual and society. Open Journal of Social Sciences, 2(8), 130-137. https://doi.org/10.4236/jss.2014.28019

Hudha, A. M., \& Husamah, H. (2019). Pendampingan implementasi model pembelajaran OIDDE untuk meningkatkan keterampilan pembelajaran berorientasi etika di MA Muhammadiyah 1 Plus Malang. International Journal of Community Service Learning, 3(3), 109-115. https://doi.org/10.23887/ijcsl.v3i3.18635

Husamah, H., Hudha, A. M., \& Pantiwati, Y. (2018). Pendampingan guru SMPN 8 Kota Malang dalam mengembangkan perilaku etis siswa berbasis model pembelajaran OIDDE. International Journal of Community Service Learning, 2(2), 41-50. https://doi.org/10.23887/ijcsl.v2i2.14185

Jeong, H., \& Hmelo-Silver, C. E. (2016). Seven affordances of computer-supported collaborative learning: How to support collaborative learning? How can technologies help? Educational Psychologist, 51(2), 247-265. https://doi.org/10.1080/00461520.2016.1158654

Jumriani, J., \& K. Prasetyo, Z. (2017). Important roles of local potency based science learning to support the 21st century learning. European Journal of Engineering and Formal Sciences, 1(1), 6-16. https://doi.org/10.26417/ejef.v1i1.p6-16

Kaendler, C., Wiedmann, M., Leuders, T., Rummel, N., \& Spada, H. (2015). Monitoring student interaction during collaborative learning: Design and evaluation of a training program for pre-service teachers. Psychology Learning and Teaching, 15(1), 44-64. https://doi.org/10.1177/1475725716638010

Le, H., Janssen, J., \& Wubbels, T. (2018). Collaborative learning practices: teacher and 
student perceived obstacles to effective student collaboration. Cambridge Journal of Education, 48(1), 103-122. https://doi.org/10.1080/0305764X.2016.1259389

Lewis, C. (2009). What is the nature of knowledge development in lesson study? Educational Action Research, 17(1), 95-110. https://doi.org/10.1080/09650790802667477

Lim, C. S., Teh, K. H., \& Chiew, C. M. (2018). Promoting and implementing lesson study in Malaysia: Issue of sustainability. In M. Quaresma, C. Winsløw, S. Clivaz, J. da Ponte, A. Ní Shúilleabháin, \& A. Takahashi (Eds.), Mathematics Lesson Study Around the World (pp. 47-64). Springer International Publishing. https://doi.org/10.1007/978-3319-75696-7_3

McKechan, S., \& Ellis, J. (2014). Collaborative learning in the Scottish curriculum for excellence: the challenges of assessment and potential of multi-touch technology. Education 3-13, 42(5), 475-487. https://doi.org/10.1080/03004279.2012.717959

Miharja, F. J., Wahyuningrum, L., Iffah, A. H., \& Eskasasnanda, I. D. P. (2020). Tokkatsu: Initiating students' collaborative activities in lesson study piloting school. Jurnal Pendidikan Progresif, 10(1), 63-72. https://doi.org/10.23960/jpp.v10.i1.202008

Nurwidodo, N., Hendayana, S., Hindun, I., \& Sarimanah, E. (2018). Strategies for establishing networking with partner schools for implementing lesson study in Indonesia. JPBI (Jurnal Pendidikan Biologi Indonesia), 4(1), 11-22. https://doi.org/10.22219/jpbi.v4i1.5489 11

Nurwidodo, N., Rahardjanto, A., Husamah, H., \& Mas'odi, M. (2018). Pendampingan Masyarakat dalam Budidaya Rumput Laut di Kepulauan Sapeken Kabupaten Sumenep Jawa Timur. International Journal of Community Service Learning, 2(3), 157-166. https://doi.org/10.23887/ijcsl.v2i3.14770

Permana, F. H., \& Pantiwati, Y. (2020). Pengelolaan modul IPA terpadu berbasis metakognisi di SMP Muhammadiyah 06 Dau Malang. International Journal of Community Service Learning, 4(1), 24-30. https://doi.org/10.23887/ijcsl.v4i1.21962

Persico, D., Pozzi, F., \& Sarti, L. (2010). Monitoring collaborative activities in computer supported collaborative learning. Distance Education, 31(1), 5-22. https://doi.org/10.1080/01587911003724603

Pluta, W. J., Richards, B. F., \& Mutnick, A. (2013). PBL and Beyond: Trends in collaborative learning. Teaching and Learning in Medicine, 25(SUPPL.1). https://doi.org/10.1080/10401334.2013.842917

Prihanta, W., Zainuri, A. M., Hartini, R., Syarifuddin, A., \& Patma, T. S. (2020). Pantai Taman-Pacitan ecotourism development: Conservation and community empowerment orientation. Journal of Community Service and Empowerment, 1(1), 1-16. https://doi.org/10.22219/jcse.v1i1.11515

Prihantoro, C. R. (2011). Pengembangan profesionalisme guru melalui model Lesson Study. Jurnal Pendidikan Dan Kebudayaan, 17(1), 100-108.

Rahardjanto, A., Nurwidodo, N., \& Mas'odi, M. (2019). Implementasi teknologi tepat guna untuk mengatasi permasalahan IRT ramuan Madura di Kabupaten Sumenep. International Journal of Community Service Learning, 3(4), 173. https://doi.org/10.23887/ijcsl.v3i4.21788

Saito, E. (2019). Perspectives on School Leadership in Asia Pacific Contexts. In Perspectives on School Leadership in Asia Pacific Contexts. Springer Singapore. https://doi.org/10.1007/978-981-32-9160-7

Saito, E., \& Atencio, M. (2015). Lesson study for learning community (LSLC): Conceptualising teachers' practices within a social justice perspective. Discourse: Studies in the Cultural Politics of Education, 36(6), 795-807. https://doi.org/10.1080/01596306.2014.968095

Saito, E., Khong, T. D. H., Hidayat, A., Hendayana, S., \& Imansyah, H. (2018). Typologies of lesson study coordination: a comparative institutional analysis. Professional 
Development in Education, $\quad$ 00(00), $\quad 1-17$. https://doi.org/10.1080/19415257.2018.1561495

Saito, E., Watanabe, M., Gillies, R., Someya, I., Nagashima, T., Sato, M., \& Murase, M. (2015). School reform for positive behaviour support through collaborative learning: utilising lesson study for a learning community. Cambridge Journal of Education, 45(4), 1-30. https://doi.org/10.1080/0305764X.2014.988684

Santoro, F. M., Borges, M. R. S., \& Santos, N. (2004). Evaluation of collaborative learning processes. Advanced Technology for Learning, 1(3), 203-221. https://doi.org/10.2316/journal.208.2004.3.208-0814

Scager, K., Boonstra, J., Peeters, T., Vulperhorst, J., \& Wiegant, F. (2016). Collaborative learning in higher education: Evoking positive interdependence. CBE Life Sciences Education, 15(4), 1-9. https://doi.org/10.1187/cbe.16-07-0219

Smith, B. L., \& MacGregor, J. T. (1992). What is collaborative learning. In Washington Center for Improving the Quality of Undergraduate Education.

Sudirtha, I. G. (2017). Membangun learning community dan peningkatkan kompetensi melalui Lesson Study. JPI (Jurnal Pendidikan Indonesia), 6(1), 28-38. https://doi.org/10.23887/jpi-undiksha.v6i1.8683

Summers, J. J., Beretvas, S. N., Svinicki, M. D., \& Gorin, J. S. (2005). Evaluating collaborative learning and community. Journal of Experimental Education, 73(3), 165188. https://doi.org/10.3200/JEXE.73.3.165-188

Susetyarini, E., \& Miharja, F. J. (2017). The implementantion of lesson study-learning community for prospective biology teachers. International Journal of Advanced Research (IJAR), 5(10), 1228-1235. https://doi.org/10.21474/IJAR01/5641

Tsuneyoshi, R. (2016). Models of schooling in the global age: the case of Japan. Revue Internationale d'education de Sevres, September, 1-5.

Ueno, M. (2007). School reform and democracy in the public theory of John Dewey: The transformation of liberalism and its ethics. Electronic Library Service Keiai University and Chiba Keiai Junior College, 167-195.

Wearmouth, J. (2017). Employing culturally responsive pedagogy to foster literacy learning in schools. Cogent Education, 4(1). https://doi.org/10.1080/2331186X.2017.1295824

Weinberger, Y., \& Shonfeld, M. (2018). Students' willingness to practice collaborative learning. Teaching Education, $00(00), \quad 1-17$. https://doi.org/10.1080/10476210.2018.1508280

Widiadi, A. N., \& Utami, I. W. P. (2016). Praksis lesson study for learning community dalam pembelajaran ilmu pengetahuan sosial melalui kolaborasi kolegial guru dan dosen. Teori Dan Praksis Pembelajaran IPS, 1(2), 77-88. https://doi.org/10.17977/jtp2ips.v1i2.8815

Wood, K. (2018). The many faces of lesson study and learning study. International Journal for Lesson and Learning Studies, 7(1), 2-7. https://doi.org/10.1108/IJLLS-10-20170047

Zaenab, S., Chamisijatin, L., \& Wahyuni, S. (2020). Strengthening character education through literacy movement at Muhammadiyah junior high schol. Journal of Community Service and Empowerment, 1(1), 54-63. https://doi.org/10.22219/jcse.v1i1.11516

Zubaidah, S. (2010). Lesson Study Sebagai Salah Satu Model Pengembangan Profesionalisme Guru. Pendidikan Dan Pelatihan Nasional: Peningkatan Profesionalisme Guru Melalui Kegiatan Lesson Study, April. 